\title{
Pemberdayaan Masyarakat Menuju Desa Tangguh Bencana di Area Terdampak Bencana Lumpur Lapindo, Sidoarjo
}

\author{
Eny Sulistyowati ${ }^{1}$, June Ekawati ${ }^{2}$ \\ Management Department ${ }^{1}$, Civil Engineering Department ${ }^{2}$, Universitas Yos \\ Soedarso, Surabaya, Indonesia \\ Email : enysulistyowati7171@gmail.com ${ }^{1}$; juneekawati@gmail.com ${ }^{2}$
}

\begin{abstract}
The economy is one of the important factors that influence the condition of vulnerability of community after a disaster. This study aims to determine the factors that are of interest to the community in starting a business by SWOT analysis of community empowerment programs in areas impacted by the Lapindo mudflow disaster, Sidoarjo, and the implementation of programs towards disaster resilient villages. The method used is a combination of quantitative and qualitative with questionnaires and in-depth interviews. The results showed that people's awareness of the importance of family savings as a disaster preparedness increased significantly even though some respondents experienced a decrease in income. The results of the SWOT analysis of the training alternatives offered to the community indicate that the factors of ease of obtaining raw materials, small initial capital requirements, mastery of the production process and market access of the products produced will attract the interest of the community to run a business. The participation of village communities in the study areas to help reduce the impact of disaster risks related to the environment around the settlements, can be encouraged by forming disaster resilient villages managed by the community themselves with the full support of the government.
\end{abstract}

Keywords: Vulnerability, community empowerment, disaster resilient villages

\section{Pendahuluan}

Secara global, tren kejadian dan skala bencana alam maupun bencana yang disebabkan manusia khususnya yang terkait dengan hydrometeorology seperti banjir dan badai angin mengalami peningkatan (Salami, Von Meding, \& Giggins, 2017). Indonesia yang secara geografis dilewati oleh garis katulistiwa, merupakan negara yang keindahan alamnya sangat dikagumi dunia namun sekaligus juga rawan bencana. Data dari BNPB menyebutkan bahwa dalam 10 tahun terakhir tren kejadian bencana juga mengalami peningkatan cukup berarti dan pada kurun waktu 2016-2018 angka kejadian bencana yang meningkat terutama bencana banjir, tanah 
longsor dan puting beliung (BNPB, 2020). Salah satu peristiwa bencana nasional yang dampaknya luas, kompleks dan penyelesaiannya sangat berlarut-larut adalah peristiwa semburan lumpur panas Lapindo di Sidoarjo yang terjadi pada tahun 2006 .

Akibat kejadian bencana yang tak terduga tersebut, dampak bencananya luar biasa bagi akivitas perekonomian masyarakat bahkan di Jawa Timur (Elika, Resnawaty, \& Gutama, 2017), demikian juga dampak lingkungan, fisik, sosial maupun budaya, bahkan masyarakat terpaksa harus direlokasi karena desanya dinyatakan tidak layak huni oleh BPLS (Mundakir, 2011). Banyak masyarakat terpaksa turun ke jalan berunjuk rasa karena penanganan ganti ruginya dianggap sangat merugikan masyarakat (Daulay, 2010). Kasus Lapindo sebenarnya adalah sebuah bencana sosial karena kerusakan yang terjadi bukanlah hanya fisik tapi juga sistem sosial masyarakat (Novenanto, 2016). Sementara upaya relokasi warga bukan perkara mudah karena relokasi bukan hanya sekedar memindahkan rumah secara fisik-geografis, tetapi juga proses sosial budaya bahkan ekonomi (Iftita \& Zurinani, n.d.). Segenap elemen bangsa saat masa tanggap darurat terus mengalirkan berbagai bantuan sebagai bentuk kepedulian dan keprihatinan. Namun setelah fase itu berakhir, korban bencana seringkali harus berjuang sendiri untuk dapat memulai hidupnya seperti sediakala (Bahransyaf, 2009).

Dampak ekonomi bencana lumpur seperti hilangnya mata pencaharian masyarakat karena tempat kerja seperti sawah dan pabrik yang ikut tenggelam dalam lumpur, sangat dirasakan masyarakat (Suryaningsih \& Handayani, 2017). Hasil kajian dari Daulay (Daulay, 2010) mengungkap enam struktur pola mekanisme survival yang dilakukan masyarakat pada fase awal pasca bencana lumpur Lapindo yaitu: menekan pengeluaran rumah tangga, pemanfaatan tenaga kerja keluarga, jaringan sosial, wisata lumpur Lapindo sebagai lahan usaha, migrasi sebagai pilihan akhir, maupun mobilisasi massa untuk unjuk rasa. Masyarakat yang terkategori secara sosial ini kemudian membentuk kehidupan baru dan berupaya mengembalikan modal ekonomi dan modal budaya mereka (Arifin, Nugroho, \& Kamajaya, 2006).

Namun setelah 14 tahun pasca bencana (2006-2020), ternyata masih banyak 
masyarakat yang belum membaik ekonomi keluarganya. Padahal mereka harus tetap bertahan di tengah kondisi lingkungan permukiman yang telah berubah. Lokasi kerja saat ini mungkin lebih jauh, sawah dan tambak ikan pun ikut tenggelam, sehingga sumber pendapatan dan tabungan keluarga menurun. Dalam kondisi seperti ini beberapa warga tentu membutuhkan pekerjaan baru atau penghasilan tambahan agar bisa mulai memperbaiki bangunan rumahnya yang rusak serta memulihkan kondisi ekonomi keluarga sehari-hari.)

Untuk pemulihan ekonomi, beberapa masyarakat mulai menekuni usaha di bidang ekonomi (Gambar 1) dengan memanfaatkan lahan tanggul lumpur sebagai obyek wisata, usaha ternak serta tambak ikan sebagai alternatif penghasilan utama maupun tambahan. Mengingat kondisi ekonomi masyarakat hingga kini masih rentan dan pemulihannya tidak bisa berjalan dengan cepat, maka program pemberdayaan ekonomi perlu terus dilakukan karena sangat dibutuhkan oleh masyarakat. Kajian mengenai pemberdayaan masyarakat berbasis hasil penelitian penting dilakukan karena pemberdayaan masyarakat merupakan salah satu upaya untuk memberikan daya atau kekuatan bagi masyarakat agar keluar dari permasalahan yang dihadapinya serta upaya memandirikan masyarakat dalam menghadapi berbagai tantangan di kehidupannya (Mustangin, Kusniawati, Islami, Setyaningrum, \& Prasetyawati, 2017).
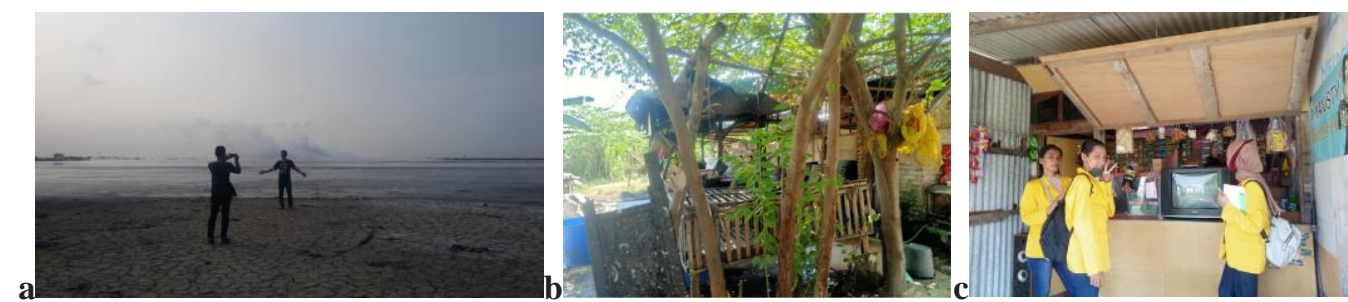

Gambar 1. Beberapa usaha masyarakat di area terdampak bencana lumpur Lapindo: a: Wisata bencana lumpur sebagai lahan usaha; b: Usaha beternak ayam di Desa Gedang; c: Usaha warung di Desa Kalitengah.

(Source: Author's documentation, 2020)

Tujuan dari penelitian ini adalah untuk mengetahui faktor-faktor yang diminati masyarakat dalam memulai usaha dengan menganalisis kekuatan, kelemahan, peluang dan tantangan terhadap program pemberdayaan ekonomi 
masyarakat di area terdampak bencana lumpur Lapindo, Sidoarjo, dan implementasi program menuju desa tangguh bencana. Adapun manfaat yang diharapkan dari hasil kajian dalam penelitian ini adalah untuk membantu upaya mengurangi risiko bencana, menurunkan tingkat kerentanan dan pemulihan kondisi ekonomi masyarakat di area terdampak bencana lumpur Lapindo, Sidoarjo, agar bisa mandiri secara ekonomi dan mampu mewujudkan desa tangguh bencana.

\section{Tinjauan Pustaka}

Ekonomi menjadi salah satu faktor penting yang mempengaruhi kondisi kerentanan pada masyarakat pasca bencana. Kerentanan ekonomi masyarakat di area terdampak bencana lumpur Lapindo ini memerlukan suatu manajemen bencana yang baik dimana proses Manajemen bencana tersebut bersifat dinamis, terpadu dan berkelanjutan untuk meningkatkan kualitas langkah-langkah yang berhubungan dengan kegiatan pencegahan, mitigasi, kesiapsiagaan, tanggap darurat, evakuasi, rehabilitasi maupun pembangunan kembali (Jokowinarno, 2011). Karenanya, Manajemen bencana di area studi tidak hanya menyangkut soal fisik dan infrastruktur untuk pengendalian semburan lumpur semata namun program mitigasi bencana perlu terus dilakukan berkala sebagai upaya mengurangi dampak bencana. Dalam UU No 24 tahun 2007 disebutkan bahwa Mitigasi adalah "serangkaian upaya untuk mengurangi risiko bencana, baik melalui pembangunan fisik maupun penyadaran dan peningkatan kemampuan menghadapi ancaman bencana", sehingga pemberdayaan ekonomi masyarakat pada dasarnya merupakan salah satu program mitigasi bencana.

Istilah "pemberdayaan" dari segi bahasa berasal dari kata "Daya" yang artinya kekuatan atau kemampuan untuk melakukan usaha. Konsep pemberdayaan (empowerment) berkaitan dengan kekuasaan (power) (Anwas, 2013; Mustangin et al. 2017). Ini berati empowerment berarti (1) to give power atau authority to atau memberi kekuasaan; dan (2) to give ability to atau enable (Hutomo, 2000), atau sebagai upaya untuk memampukan dan memandirikan masyarakat (Fahrudin, 2012) yang dilakukan dengan cara: 1) Enabling (menciptakan suasana atau iklim yang memungkinkan potensi masyarakat berkembang); 2) Empowering 
(meningkatkan kapasitas dengan memperkuat potensi atau daya yang dimiliki masyarakat) 3) Protecting (melindungi kepentingan dengan mengembangkan sistem perlindungan bagi masyarakat yang menjadi subjek pengembangan).

Disebutkan dalam "The 6-Step Model for Community Empowerment" langkah pemberdayaan yaitu: masuk ke masyarakat, identifikasi permasalahan, prioritasi masalah, pengembangan strategi, implementasi, dan transisi (Reizkapuni \& Rahdriawan, 2014; Yoo, Butler, Elias, \& Goodman, 2008). Adapun tujuan pemberdayaan masyarakat adalah untuk mempercepat dan memperluas upaya penanggulangan kemiskinan melalui koordinasi berbagai kebijakan, program dan kegiatan pembangunan di tingkat pusat maupun daerah sehingga efektivitasnya signifikan terhadap penanggulangan kemiskinan (Arsiyah, Ribawanto, \& Sumartono, 2009).

Dengan adanya program pemberdayaan yang bertujuan untuk perbaikan kehidupan masyarakat (better community), maka diharapkan bahwa desa-desa yang terdampak bencana lumpur Lapindo ini dapat tumbuh menjadi desa tangguh bencana (disaster resilient village) yang akan meningkatkan pertumbuhan budaya aman dan tangguh di masyarakat, dimana nilai-nilai sosial yang ada di masyarakat lokal inilah yang menjadi modal dasar dalam membangun desa tangguh bencana (Maarif, Damayanti, Suryanti, \& Wicaksono, 2012). Desa tangguh bencana sendiri didefinisikan sebagai unit terkecil permukiman di area pedesaan yang warganya memiliki karakter pantang menyerah dan motivasi tinggi untuk menanggulangi bencana (Maarif et al., 2012) atau suatu desa yang memiliki kemampuan mandiri untuk beradaptasi menghadapi potensi ancaman bencana dan segera pulih dari dampak yang merugikan (Saroji, Mahdi, \& Srimulyani, 2016).

Habibullah (2013) mengemukakan bahwa masyarakat desa tangguh bencana harus terlibat aktif dalam mengkaji, menganalisis, menangani, memantau, mengevaluasi dan mengurangi risiko bencana di wilayah mereka, terutama dengan memanfaatkan sumber daya lokal demi menjamin keberlanjutan. Adapun tujuan pembentukan desa tangguh bencana (Oktari, 2019) adalah: 1) Melindungi masyarakat di kawasan rawan dari bencana; 2) Meningkatkan peran serta masyarakat dalam pengelolaan sumber daya dalam mengurangi risiko bencana; 3) 
Meningkatkan kapasitas kelembagaan masyarakat desa; 4) Meningkatkan kapasitas aparat desa; 5) Meningkatkan kerjasama antara para pemangku kepentingan dalam Pengurangan Risiko Bencana.

Sebagai contoh untuk studi komparasi tingkat pemulihan yang cukup baik dari kota yang juga pernah mengalami bencana alam berskala besar yaitu Padang, dimana dalam segi kesiapsiagaan terhadap bencana, rumah tangga di Padang dinilai relatif mampu dalam upaya pemulihan ekonominya pasca bencana. Karakter masyarakat Padang dari segi sosial dipengaruhi oleh budaya Minangkabau yang kuat dalam pola pertanian dan perdagangan. Dengan kondisi ekonomi masyarakat tergolong cukup baik, maka tingkat kebertahanan ekonominya juga tinggi (Ekawati, Hardiman, \& Pandelaki, 2020; Kusumastuti, Viverita, Husodo, Suardi, \& Danarsari, 2014). Hal ini dapat menjadi inspirasi bagi desa-desa terdampak bencana di Sidoarjo untuk meningkatkan kapasitasnya dalam mengatasi kerentanan terhadap bahaya dan dampak bencana untuk mewujudkan desa tangguh.

\section{Metode Penelitian}

Area studi yang dipilih adalah tiga desa yang terdampak bencana lumpur Lapindo, Sidoarjo, Jawa Timur, yaitu Desa Kalitengah Kecamatan Tanggulangin, Desa Glagaharum Kecamatan Porong dan Desa Gedang Kecamatan Porong. Adapun metode yang digunakan dalam penelitian mengenai "Pemberdayaan ekonomi masyarakat menuju desa tangguh bencana" yang bersifat kuantitatif dan kualitatif ini menggunakan wawancara mendalam (In depth interview) dan alat bantu kuesioner untuk menggali data primer dari masyarakat. Wawancara sangat diperlukan untuk menanyakan beberapa pertanyaan yang memerlukan jawaban penjelasan berupa proses (deskriptif) yang tidak terukur. Dengan demikian maka sumber data dalam penelitian ini terdiri atas data primer dan data sekunder yaitu:

1. Data Primer yang diperoleh secara langsung di lapangan, berupa : a) Foto kondisi eksisting wilayah penelitian yaitu kondisi lingkungan dan permukiman di 3 desa yang ada di 2 kecamatan; b) Wawancara dengan perangkat desa, tokoh masyarakat; c) kuesioner kepada masyarakat. 
2. Data sekunder yang diperoleh di Kantor Kepala Desa, maupun buku dan hasil penelitian terdahulu yang relevan.

Jumlah responden sekaligus narasumber dari ketiga desa adalah 117 orang dengan perincian Desa Glagaharum terdapat dari 34 responden dari 4.144 jumlah penduduk, Desa Gedang 28 responden dari 6.325 penduduk, dan dari Desa Kalitengah adalah 55 responden dari 12.978 penduduk. Jumlah responden disesuaikan dengan prosentase jumlah penduduk. Namun untuk Desa Glagaharum, jumlah responden memang ditambah mengingat banyaknya rumah warga yang berdekatan dengan dinding tanggul lumpur.

\section{Hasil Dan Pembahasan}

\subsection{Kondisi Lokasi Studi}

Ketiga desa yang menjadi lokasi studi terletak di sekitar dinding tanggul lumpur Lapindo, dimana sebagian masyarakatnya juga direlokasi akibat terdampak bencana. Desa Glagaharum Kecamatan Porong berada tepat di tepi Timur dinding tanggul. Desa Gedang Kecamatan Porong sebenarnya berada tepat di seberang jalan dari dinding tanggul, namun sebagian masyarakatnya juga direlokasi. Demikian pula dengan Desa Kalitengah Kecamatan Tanggulangin yang berada tepat di sebelah Barat Laut dan Utara dinding tanggul, sebagian masyarakatnya direlokasi akibat terdampak bencana.
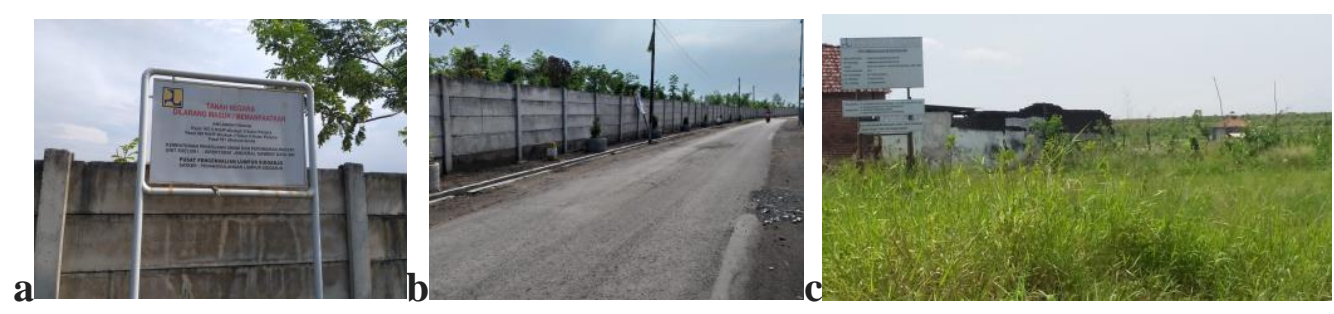

Gambar 2. Kondisi lokasi studi di area terdampak bencana lumpur Lapindo: a: Papan peringatan; b: Pagar pembatas beton dari tanah yang telah dikuasai PPLS; c. Lahan tepi tanggul di Desa Kalitengah yang dikelola PPLS dengan rumput yang meninggi (Sumber: Author's documentation, 2020)

Lokasi lahan dan permukiman masyarakat yang masuk dalam peta terdampak bencana dari pemerintah (dalam pengelolaan PPLS-PUPR) saat ini telah diberi batas pagar beton dengan papan peringatan dan sebagian besar telah ditinggalkan 
oleh pemiliknya. Namun sebagian masyarakat tidak bersedia pindah dan tetap bertahan di lokasi tersebut dengan berbagai alasan. Kondisi fisik lokasi tersebut saat ini sangat memprihatinkan dengan rumput yang tumbuh meninggi dan beberapa sisa bangunan rumah yang rusak berat (Gambar 2).

\subsection{Hasil Data Kuesioner}

Pasca bencana, masyarakat mengalami perubahan ekonomi cukup signifikan akibat tempat kerja seperti pabrik dan area persawahan terendam lumpur sehingga mereka kehilangan lapangan pekerjaan. Keadaan ini tentu memaksa masyarakat untuk mencari pekerjaan lain guna memenuhi kebutuhan hidup sehari-hari (Suryaningsih \& Handayani, 2017).

Dari hasil kuesioner yang diisi oleh responden, diperoleh data diri responden sebagaimana tabel 1 berikut:

Tabel 1. Data Responden Penelitian dalam Persen

\begin{tabular}{|c|c|c|c|c|}
\hline No. & Data & Glagaharum & Gedang & Kalitengah \\
\hline \multirow[t]{5}{*}{1.} & Usia Responden & & & \\
\hline & a. $0-15$ tahun & 0.00 & 3.57 & 0.00 \\
\hline & b. 16-30 tahun & 0.00 & 32.14 & 3.64 \\
\hline & c. $31-40$ tahun & 0.00 & 28.57 & 30.91 \\
\hline & d. Di atas 40 tahun & 100.00 & 35.71 & 65.45 \\
\hline \multirow[t]{12}{*}{2.} & Pendidikan terakhir & & & \\
\hline & a. S2-S3 & 0.00 & 0.00 & 0.00 \\
\hline & b. S1 & 0.00 & 0.00 & 1.82 \\
\hline & c. SMA & 8.82 & 35.71 & 21.82 \\
\hline & d. SMP & 41.18 & 25.00 & 20.00 \\
\hline & e. SD & 50.00 & 39.29 & 56.36 \\
\hline & Pekerjaan & & & \\
\hline & a. PNS/BUMN & 0.00 & 0.00 & 1.82 \\
\hline & b. Pekerja Swasta & 0.00 & 53.57 & 16.36 \\
\hline & c. Wiraswasta & 0.00 & 0.00 & 0.00 \\
\hline & d. Pelajar/mhsiswa & 0.00 & 7.14 & 0.00 \\
\hline & $\begin{array}{l}\text { e.Petani/pekerja in- } \\
\text { formal/ tidak tetap }\end{array}$ & 100.00 & 39.29 & 81.82 \\
\hline
\end{tabular}

Sumber : Diolah Penulis dari data kuesioner, 2020

Dari tabel 1 didapatkan hasil bahwa untuk faktor usia, diperoleh data bahwa usia responden sebagian besar berada di atas 40 tahun. Bahkan untuk Desa Glagaharum 100\% responden berusia di atas 40 tahun, yang berarti berada di usia produktif dan lansia. Untuk desa Desa Gedang, distribusi usia produktif dari 16 hingga di atas 40 tahun sangat baik dan hampir merata. Sedangkan untuk Desa 
Kalitengah, distribusi usia terbesar hanya berada pada 2 kategori yaitu 31-40 tahun sebanyak $31 \%$ dan sekitar $65 \%$ berusia di atas 40 tahun.

Dari sisi tingkat pendidikan, ternyata sebagian besar didominasi oleh tingkat SD, dimana untuk Desa Glagaharum ada 50\% responden, Desa Gedang sebanyak 39.29\%, dan Desa Kalitengah 56.36\% responden yang berpendidikan SD. Bila ditinjau dari faktor profesi penduduk, dapat diketahui juga sebagian besar responden (Desa Glagaharum 100\% dan Kalitengah 81.82\%) memiliki profesi pada kategori 1 yaitu petani / pekerja informal / pekerja tidak tetap. Sedangkan untuk Desa Gedang, profesi terbanyak yaitu $53.57 \%$ adalah pegawai swasta, sedangkan profesi pada kategori 1 berjumlah 39.29\%.

Dari data di atas, dapat diketahui bahwa dari segi profesi masyarakat sebagai petani yang menggantungkan hidupnya dari hasil lahan, maka dapat dimaklumi bahwa masyarakat bertipe agraris memang sulit meninggalkan lahan pertaniannya dan mengalihkan profesinya ke tipe industri. Apalagi tingkat pendidikan masyarakat sangat terbatas dan semua ilmu yang dimiliki memang hanya soal pengolahan tanah yang didapatkan secara turun-temurun. Untuk itu maka berbagai pelatihan ketrampilan dalam kerangka kegiatan program pemberdayaan ekonomi sangat dibutuhkan agar masyarakat bisa mendapatkan tambahan penghasilan dan mampu mandiri.

Tabel 2. Pendapatan, Belanja dan Tabungan Responden Penelitian

\begin{tabular}{lrrr}
\hline \multicolumn{1}{c}{ Desa } & $\begin{array}{c}\text { Sumber } \\
\text { Pendapatan (\%) }\end{array}$ & $\begin{array}{c}\text { Belanja / } \\
\text { Pengeluaran (\%) }\end{array}$ & Tabungan (\%) \\
\hline Glagaharum & & & \\
- Sangat meningkat & 2.94 & 0.00 & 32.35 \\
- Ada peningkatan & 0.00 & 35.29 & 61.76 \\
- Relatif stabil/tetap & 61.76 & 0.76 & 5.88 \\
- Menurun & 35.29 & 2.94 & 0.00 \\
- Sangat menurun & 0.00 & & 0.00 \\
\hline Gedang & & 7.14 & \\
- Sangat meningkat & 25.00 & 14.29 & 35.00 \\
- Ada peningkatan & 28.57 & 35.71 & 25.71 \\
- Relatif stabil/ tetap & 35.71 & 28.57 & 10.71 \\
- Menurun & 10.71 & 14.29 & 3.57 \\
- Sangat menurun & 0.00 & & \\
\hline Kalitengah & & 1.82 & 3.64 \\
- Sangat meningkat & 0.00 & 18.18 & 30.91 \\
- Ada peningkatan & 23.64 & 49.09 & 49.09 \\
\hline
\end{tabular}




\begin{tabular}{lrrr}
\hline - Menurun & 23.64 & 25.45 & 7.27 \\
- Sangat menurun & 9.09 & 5.45 & 9.09 \\
\hline \multicolumn{2}{l}{ Sumber : Diolah Penulis dari data kuesioner, 2020 }
\end{tabular}

Bila dicermati hasil kuesioner pada tabel 2, terdapat beberapa hal yang cukup menarik dicermati. Untuk Desa Glagaharum, terdapat 35.29\% responden yang menyebutkan bahwa sumber pendapatannya menurun setelah terjadinya bencana. Namun di sisi belanja terlihat bahwa sejumlah $35.29 \%$ tersebut mengatakan bahwa dari sisi belanja terdapat peningkatan. Hal ini berarti bahwa pada warga Desa Glagaharum, peningkatan belanja tersebut tidak diimbangi dengan meningkatnya sumber pendapatan atau masyarakat berada pada kondisi ekonomi yang cukup rentan. Pada Desa Gedang, hanya $10.71 \%$ responden menyatakan sumber pendapatannya menurun, namun $42.86 \%$ responden justru menurun jumlah belanjanya. Perbedaan ini cukup signifikan. Kemungkinan adalah peningkatan pendapatan cukup tinggi dan kurang seimbang dengan belanja sehingga dirasakan menurun. Sedangkan pada Desa Kalitengah, dari sebanyak $32.73 \%$ responden yang menurun sumber pendapatannya, $30.90 \%$ responden menyebut bahwa belanjanya mengalami penurunan. Jumlah ini tentunya masih relatif seimbang.

Adapun pembahasan mengenai tabungan keluarga masyarakat juga sangat menarik. Walaupun 39.29\% sumber pendapatan warga Desa Glagaharum turun, namun $94.11 \%$ responden menyatakan bahwa tabungannya meningkat. Data ini menunjukkan bahwa kesadaran warga akan pentingnya tabungan keluarga sebagai upaya kesiapsiagaan (preparedness) bencana meningkat secara signifikan. Demikian pula halnya dengan kondisi masyarakat Desa Gedang dan Kalitengah. Prosentase masyarakat yang menyatakan tabungan keluarganya menurun hanya berjumlah 14.28\% (Desa Gedang) dan 16.36\% (Desa Kalitengah). Penulis sependapat dengan Arifin dkk (Arifin et al., 2006) bahwa masyarakat memang berupaya keras untuk mengembalikan modal ekonomi dan modal budaya mereka.

\subsection{Progam Pemberdayaan Masyarakat}

Kemampuan masyarakat untuk beradaptasi atau mengatasi masalah akan berbanding lurus dengan kondisi sosial-ekonomi masyarakat. Karena itu jika 
tingkat ekonomi masyarakat rendah, maka masyarakat tidak berdaya dalam meningkatkan kualitas lingkungannya, sehingga diperlukan adanya upaya meningkatkan power masyarakat dengan melakukan kegiatan pemberdayaan (Reizkapuni \& Rahdriawan, 2014).

Program pemberdayaan maasyarakat yang diadakan oleh Pemerintah Kabupaten Sidoarjo berupa pelatihan ketrampilan yang tujuannya adalah menciptakan lapangan kerja baru serta memungkinkan warga terdampak bencana lumpur Lapindo bisa menyerap berbagai ketrampilan, keahlian dan kemahiran sebagai bekal memasuki dunia usaha untuk memperoleh penghasilan tambahan dari pelatihan ketrampilan ini. Berbagai pelatihan ini sesuai dengan cara pemberdayaan masyarakat (Fahrudin, 2012) yaitu enabling, empowering dan protecting. Adapun kegiatan yang telah diadakan diantaranya adalah menjahit, membuat kerajinan tas dan bordir serta beternak ikan seperti ikan lele.

Sayangnya dari hasil wawancara yang didapatkan peneliti di lapangan, masyarakat menyebut bahwa berbagai program pelatihan dari pemerintah daerah memang pernah ada pada fase awal pasca bencana. Saat ini sudah tidak pernah ada lagi kegiatan semacam itu sehingga efektvitasnya menjadi kurang signifikan dalam upaya penanggulangan kemiskinan (Arsiyah et al., 2009). Sementara masyarakat masih sangat membutuhkan pendampingan dan pelatihan ketrampilan lainnya agar dapat memulai usaha untuk menambah penghasilan keluarga.

Beberapa program pelatihan ketrampilan yang telah diadakan oleh pemerintah daerah tentu perlu diapresiasi karena tujuannya adalah untuk dapat mengatasi dampak ekonomi seperti masalah pengangguran yang timbul akibat bencana. Namun efektifitas dan tingkat keberhasilan dari pelatihan-pelatihan tersebut masih belum memberikan empowerment, strengthening, memampukan, memandirikan (Fahrudin, 2012) dan memenuhi harapan masyarakat karena hanya sebagian kecil masyarakat saja yang dapat menguasai berbagai ketrampilan tersebut serta berlanjut menjadi pengrajin tas dan bordir.

Untuk menentukan ragam ketrampilan yang sesuai bagi masyarakat di suatu tempat, kiranya perlu ada berbagai kajian sebagaimana “The 6-Step Model for Community Empowerment" yaitu: masuk ke masyarakat, identifikasi permasalahan, 
prioritasi masalah, pengembangan strategi, implementasi, dan transisi (Reizkapuni \& Rahdriawan, 2014; Yoo et al., 2008) seperti :

- Masuk ke masyarakat, mengidentifikasi dan membuat proritasi masalah;

- Mengembangkan strategi dengan mengenali potensi daerah dan lingkungan sekitarnya, latar belakang pendidikan dan minat masyarakat;

- Mengimplementasikan program dengan melihat kemampuan modal kerja masyarakat dalam penyediaan peralatan dan bahan baku serta ketersediaan bahan baku yang dibutuhkan untuk rintisan industri kecil;

- Daya serap pasar terhadap produk industri rintisan masyarakat;

- Pelaksanaan pelatihan dan pendampingan usaha masyarakat bisa bekerja sama dengan perguruan tinggi maupun LSM. Hal ini perlu sebagai langkah dalam fase transisi sebelum masyarakat mampu mandiri menjalankan usahanya dengan baik.

Selain ketrampilan membuat kerajinan tas kulit dan bordir, perlu kiranya beberapa alternatif pelatihan ketrampilan lain yang mungkin lebih diminati masyarakat. Berikut adalah beberapa alternatif pelatihan untuk pemberdayaan yang bisa ditawarkan kepada masyarakat seperti :

1. Ketrampilan membuat asesoris

2. Ketrampilan membuat aneka suvenir sebagai produk oleh-oleh Kota Sidoarjo;

3. Ketrampilan membuat aneka krupuk seperti krupuk ikan dan krupuk udang, krupuk kupang maupun aneka rengginang;

4. Ketrampilan membuat inovasi olahan ikan bandeng, udang atau produk laut lainnya sebagai produk unggulan Sidoarjo;

5. Ketrampilan membuat sambal kemasan khas Sidoarjo yang diminati pasar;

6. Ketrampilan membuat aneka produk kerajinan dari bahan limbah seperti botol plastik bekas dan limbah sisa kulit bahan baku kerajinan tas.

7. Ketrampilan beternak ikan konsumsi dan ikan hias, ayam, kambing atau sapi;

8. Pelaksanaan pembangunan infrastruktur desa oleh masyarakat dengan dana desa dari pemerintah pusat.

Ragam alternatif pelatihan ketrampilan untuk masyarakat di atas dipilih berdasarkan pertimbangan bahwa area terdampak bencana lumpur Lapindo 
berpotensi untuk dijadikan kawasan wisata edukasi karena kawasan ini memiliki daya tarik yang unik dan berbeda dengan lokasi wisata lainnya (Abdillah \& Suryawan, 2019). Meski menggembirakan jika rencana ini terealisasi, namun pengembangan kawasan wisata memerlukan pertimbangan matang akan ancaman bahaya dan tingkat risiko bencana di masa mendatang.

Dengan beragam jenis ketrampilan yang diberikan oleh pemerintah daerah dalam kerangka mitigasi bencana dengan pemberdayaan masyarakat dan pendampingan dalam perintisan usaha kecil, maka perekonomian masyarakat diharapkan akan meningkat dan berhasil menciptakan lapangan kerja sendiri. Pembentukan BUMDes dirasa perlu untuk menjembatani produk masyarakat yang butuh pemasaran atau bahan baku. Dengan tingkat ekonomi yang lebih kuat, tentunya periode pemulihan akan makin cepat dan upaya mewujudkan desa tangguh bencana di area ini juga akan segera dapat terealisasi dengan baik.

Untuk mengimplementasikan berbagai jenis ketrampilan di atas menjadi suatu rintisan usaha kecil masyarakat, diperlukan analisis mendalam menggunakan analisis SWOT pada tabel 3 berikut ini :

Tabel 3. Analisis SWOT

\begin{tabular}{|c|c|c|c|c|}
\hline $\begin{array}{c}\text { Program Rintisan } \\
\text { Bisnis }\end{array}$ & Strength & Weakness & Opportunity & Threat \\
\hline $\begin{array}{l}\text { Bisnis membuat } \\
\text { asesoris }\end{array}$ & $\begin{array}{l}\text { - Bahan baku } \\
\text { relatif mudah } \\
\text { - Modal awal } \\
\text { kecil }\end{array}$ & $\begin{array}{l}\text {-Bidang baru } \\
\text {-Belum tram pil } \\
\text { \& pengalaman } \\
\text {-Perlu networ } \mathrm{k} \\
\text { baru }\end{array}$ & $\begin{array}{l}\text {-Perlu tekun } \\
\text {-Pasarnya baik }\end{array}$ & $\begin{array}{l}\text { - Perlu berlatih } \\
\text { agar produk- } \\
\text { nya laku } \\
\text { - Harga mengi } \\
\text { kuti pasar } \\
\end{array}$ \\
\hline $\begin{array}{l}\text { Aneka suvenir } \\
\text { sebagai produk oleh- } \\
\text { oleh }\end{array}$ & $\begin{array}{l}\text { - Bahan baku } \\
\text { mudah } \\
\text { - Modal awal } \\
\text { kecil }\end{array}$ & $\begin{array}{l}\text {-Bidang baru } \\
\text {-Belum trampil } \\
\text { \& pengalaman } \\
\text {-Perlu networ k } \\
\text { baru }\end{array}$ & $\begin{array}{l}\text {-Perlu tekun } \\
\text {-Pasarnya baik }\end{array}$ & $\begin{array}{l}\text { - Perlu berlatih } \\
\text { agar produk- } \\
\text { nya laku } \\
\text { - Harga mengi } \\
\text { kuti pasar } \\
\end{array}$ \\
\hline $\begin{array}{l}\text { Aneka krupuk / } \\
\text { rengginang }\end{array}$ & $\begin{array}{l}\text { - Bahan baku } \\
\text { mudah } \\
\text { - Modal awal } \\
\text { kecil }\end{array}$ & $\begin{array}{l}\text { Belum trampil } \\
\& \text { pengalaman }\end{array}$ & $\begin{array}{l}\text { - Pasarnya lu- } \\
\text { as, bisa online } \\
\& \text { Kerjasama } \\
\text { dengan toko } \\
\text { oleh-oleh }\end{array}$ & $\begin{array}{l}\text { Perlu terus } \\
\text { mencoba agar } \\
\text { produk diteri- } \\
\text { ma pasar }\end{array}$ \\
\hline $\begin{array}{l}\text { Inovasi olahan ikan } \\
\text { bandeng, udang atau } \\
\text { produk laut lainnya }\end{array}$ & $\begin{array}{l}\text { - Bahan baku } \\
\text { mudah } \\
\text { - Modal alat \& } \\
\text { bahan agak } \\
\text { tinggi }\end{array}$ & $\begin{array}{l}\text {-Belum trampil } \\
\text { \& pengalaman } \\
\text {-Jika tdk berhsl, } \\
\text { masy bisa hbs } \\
\text { modal } \\
\text {-Perlu modal } \\
\text { lebih kuat }\end{array}$ & $\begin{array}{l}\text { - Perlu tekun } \\
\text { - Pasarnya lu- } \\
\text { as, bisa online } \\
\text { \& Kerjasama } \\
\text { dg toko oleh- } \\
\text { oleh }\end{array}$ & $\begin{array}{l}\text { Perlu trs men } \\
\text { coba agar pro } \\
\text { duk diterima } \\
\text { pasar }\end{array}$ \\
\hline
\end{tabular}




\begin{tabular}{|c|c|c|c|c|}
\hline $\begin{array}{l}\text { Membuat sambal } \\
\text { botol khas Sidoarjo }\end{array}$ & $\begin{array}{l}\text { - Bahan baku } \\
\text { mudah } \\
\text { - Masy sdh bia } \\
\text { sa membuat } \\
\text { - Modal kecil }\end{array}$ & $\begin{array}{l}\text { Perlu latihan } \\
\text { pengemasan } \\
\text { dan kontrol } \\
\text { kualitas }\end{array}$ & $\begin{array}{l}\text { - Perlu tekun } \\
\text { - Pasarnya lu- } \\
\text { as, bisa online } \\
\text { \& Kerjasama } \\
\text { dg toko oleh2 }\end{array}$ & $\begin{array}{l}\text { Perlu trs men } \\
\text { coba agar pro } \\
\text { duk disukai }\end{array}$ \\
\hline $\begin{array}{l}\text { Membuat aneka } \\
\text { produk kerajinan } \\
\text { dari bahan limbah }\end{array}$ & $\begin{array}{l}\text { - Bahan baku } \\
\text { mudah } \\
\text { - modal kecil }\end{array}$ & $\begin{array}{l}\text {-Bidang baru } \\
\text {-Belum trampil } \\
\text { \& pengalaman }\end{array}$ & $\begin{array}{l}\text { - Perlu tekun } \\
\text { - Penjualan bi- } \\
\text { sa online, Inta- } \\
\text { ko\& dinas kab. }\end{array}$ & $\begin{array}{l}\text { Perlu trs men } \\
\text { coba agar pro } \\
\text { duk disukai }\end{array}$ \\
\hline Beternak & $\begin{array}{c}\text { - Produk kebu- } \\
\text { tuhan sehari- } \\
\text { hari masyrkt }\end{array}$ & $\begin{array}{l}\text { Butuh modal } \\
\text { cukup besar }\end{array}$ & $\begin{array}{l}\text { Konsumen luas } \\
\& \text { selalu ada }\end{array}$ & $\begin{array}{l}\text { Harga fluktu- } \\
\text { atif }\end{array}$ \\
\hline $\begin{array}{l}\text { Membangun infra } \\
\text { struktur desa oleh } \\
\text { masyarakat dengan } \\
\text { dana desa }\end{array}$ & $\begin{array}{l}\text { Modal dana } \\
\text { pemerintah }\end{array}$ & $\begin{array}{l}\text { Pelaksanaan } \\
\text { tidak lama }\end{array}$ & $\begin{array}{l}\text { Pendpatan utk } \\
\text { modal usaha }\end{array}$ & $\begin{array}{l}\text { Manajemen } \\
\text { keuangan hrs } \\
\text { lebih baik }\end{array}$ \\
\hline
\end{tabular}

Sumber : Hasil analisis Penulis, 2020

Dari analisis SWOT pada tabel 3 di atas didapatkan kesimpulan bahwa ragam alternatif pelatihan ketrampilan yang diminati masyarakat untuk bisa mulai merintis usaha mikro kecil dan menengah (UMKM) adalah :

- Bahan bakunya mudah didapatkan;

- Ketrampilan dalam proses produksinya mudah dikuasai dengan baik;

- Modal alat dan bahan cukup terjangkau;

- Pasar hasil produksinya luas.

Untuk itu maka pemerintah daerah bisa memfasilitasi pelatihan-pelatihan ini dengan: a)Menjalin kerja sama dengan LSM atau perguruan tinggi untuk melakukan pelatihan dan pendampingan; b) Membantu akses masyarakat ke lembaga keuangan atau memberikan stimulus modal usaha dengan subsidi dan bunga rendah; c) Membantu pemasaran hasil produksi masyarakat dengan memfasilitasi kerjasama dengan mitra kerja usaha yang telah mapan.

\subsection{Implementasi Desa Tangguh Bencana}

Berdasarkan RTRW Kabupaten Sidoarjo tahun 2009-2029 pasal 54 ayat 2 dan 3 maka desa-desa yang menjadi lokasi penelitian ini merupakan kawasan yang rawan gempa, gerakan tanah dan longsor serta zona tidak layak huni. Karena itu, selain membutuhkan program pemberdayaan masyarakat agar periode pemulihan dapat dipercepat, dibutuhkan pula program desa tangguh bencana yang merupakan suatu upaya peningkatan program penanggulangan bencana berbasis masyarakat. 
Masyarakat desa tangguh bencana harus terlibat aktif dalam mengkaji, menganalisis, menangani, memantau, mengevaluasi dan mengurangi risiko bencana di wilayah mereka (Habibullah, 2013).

Adapun langkah-langkah yang dapat dilakukan dalam mempersiapkan desa tangguh bencana di area terdampak bencana lumpur Lapindo, Sidoarjo, adalah: (a) Pengkajian risiko bencana di masing-masing desa; (b) Inisiasi dan sosialisasi desa tangguh bencana ke masyarakat; (c) Pembentukan forum pengurangan risiko bencana tingkat desa; dan (d) Peningkatan kapasitas masyarakat dan perangkat desa dalam penanggulangan bencana.

Untuk menginisiasi dan sosialisasi program desa tangguh bencana ke masyarakat, perlu diadakan beberapa kegiatan inisiasi sekaligus sebagai upaya peningkatan kapasitas masyarakat maupun aparat desa dalam program penanggulangan bencana langkah berikut:

1. Memperkenalkan model desa tangguh bencana kepada masyarakat;

2. Memberikan berbagai pengarahan, pendidikan dan pelatihan tentang manajemen bencana secara berkala kepada masyarakat seperti konsep pengenaan bencana, konsep manajemen bencana, sistem peringatan dini pelatihan mobilisasi, evakuasi, pertolongan pertama; maupun perencanaan operasional (Maarif et al., 2012);

3. Melibatkan berbagai organisasi kemasyarakatan seperti pemerintah desa, LSM, PKK, organisasi budaya maupun keagamaan yang sudah ada.

4. Meningkatkan pengetahuan masyarakat dan perangkat desa dengan Pelatihan PAR (Participatory Action Research) untuk mengenal kearifan lokal pengurangan risiko bencana serta mengintensifkan diskusi-diskusi mengenai penanganan bencana dengan melibatkan berbagai elemen seperti PKK, Karang Taruna, posyandu bahkan tokoh masyarakat dan tokoh agama setempat dalam berbagai event rembug desa dan majelis taklim.

Sebagai tindak lanjut dari kegiatan sosialisasi desa tangguh bencana kepada masyarakat, maka perlu adanya pembentukan forum pengurangan risiko bencana tingkat desa yang secara intensif melakukan menyusun berbagai strategi dan langkah operasionalisasi program desa tangguh bencana. 
Program ini kemudian dilanjutkan dengan upaya peningkatan kapasitas warga dan aparat dalam penanggulangan bencana, pengintegrasian program Pengurangan Risiko Bencana ke dalam Rencana Pembangunan Desa, dan pelaksanaan program tersebut di tingkat desa. Selanjutnya juga diperkuat dengan program pemberdayaan ekonomi dengan mengadakan beberapa pelatihan ketrampilan untuk meningkatkan ekonomi masyarakat. Dengan demikian maka program desa tangguh bencana sebenarnya juga merupakan program pemberdayaan masyarakat yang dapat sekaligus berjalan beririsan dan beriringan dengan program pemberdayaan ekonomi masyarakat untuk meningkatkan kemandirian ekonomi serta kebertahanan masyarakat desa tersebut dalam menghadapi bencana.

\section{Kesimpulan}

Kesimpulan dari penelitian pemberdayaan masyarakat menuju desa tangguh bencana di area terdampak bencana lumpur Lapindo, Sidoarjo, adalah bahwa ekonomi menjadi salah satu faktor penting yang mempengaruhi kondisi kerentanan pada masyarakat pasca bencana, dimana untuk mempercepat upaya pemulihan pasca bencana maka kegiatan pemberdayaan masyarakat terutama di bidang ekonomi perlu menjadi perhatian utama pemerintah pada area-area yang terdampak bencana.

Data kuesioner responden dari ketiga desa lokasi studi menunjukkan bahwa kesadaran warga akan pentingnya tabungan keluarga sebagai upaya kesiapsiagaan (preparedness) bencana meningkat secara signifikan walaupun sebagian dari responden mengalami penuurunan dari segi pendapatan.

Beberapa program pelatihan ketrampilan yang telah diadakan oleh pemerintah daerah perlu diapresiasi, namun efektifitas dan tingkat keberhasilannya masih belum memberikan empowerment, strengthening, memampukan, memandirikan dan memenuhi harapan masyarakat. Karena itu perlu dilakukan kajian mendalam serta memberikan alternatif pelatihan ketrampilan lain yang lebih beragam sesuai dengan minat dan kemampuan masyarakat. Hasil analisis SWOT dari alternatif pelatihan yang ditawarkan pada masyarakat menunjukkan bahwa faktor kemudahan dalam perolehan bahan baku, modal awal kecil, penguasaan 
proses produksi dan akses pasar dari produknya akan menarik minat minat masyarakat untuk mulai merintis usahanya.

Penanganan dampak bencana lumpur Lapindo yang hingga kini terus dilakukan oleh PPLS (Pusat Penanggulangan Lumpur Sidoarjo) Kementrian PUPR hanya berfokus pada masalah teknis penanganan semburan lumpur dengan mengalirkan air ke sungai serta memperkuat dinding tanggul. Dalam hal ini sebenar-nya pemerintah daerah melalui BPBD dapat memfasilitasi untuk melibatkan masyarakat di desa-desa terdampak bencana agar dapat berpartisipasi aktif dan membantu mengatasi masalah terutama mengurangi dampak risiko bencana yang terkait dengan lingkungan di sekitar permukiman masing-masing desa. Partisipasi ini dapat dilakukan dengan membentuk desa tangguh bencana yang dikelola oleh masyarakat sendiri dengan dukungan penuh pemerintah.

\section{Saran}

Kegiatan pemberdayaan masyarakat dalam bidang ekonomi maupun pembentukan desa tangguh bencana yang bertujuan untuk meningkatkan kualitas langkah-langkah yang berhubungan dengan kegiatan pencegahan, mitigasi, kesiapsiaga-an, tanggap darurat, evakuasi, rehabilitasi maupun pembangunan kembali adalah bagian tak terpisahkan dari Manajemen bencana yang sifatnya berkelanjutan. Karena itu maka program tersebut bukan hanya dilakukan pada fase awal pasca bencana, namun harus secara simultan dilakukan dan pemerintah perlu terus memberi dorongan agar masyarakat juga berpartisipasi aktif dan memiliki budaya kemandirian dan menggembangkan kearifan lokal dalam penanggulangan bencana.

Pemberdayaan masyarakat bukan hanya untuk meningkatkan produktivitas, memberikan kesempatan berusaha, memberikan suntikan dan akses modal sebagai stimulan, tetapi pemerintah juga perlu memfasilitasi kerjasama dan kemitraan dengan unit usaha yang telah maju. Pemerintah perlu terus mendorong pembentukan desa tangguh di area terdampak bencana lumpur Lapindo ini dan dapat dilakukan beriringan dengan program pemberdayaan ekonomi masyarakat untuk meningkatkan kemandirian ekonomi serta kebertahanan masyarakat desa tersebut dalam kerangka program manajemen dan mitigasi bencana. 


\section{ACKNOWLEDGEMENT}

Penelitian ini didanai oleh Kementrian Riset dan Teknologi - Badan Riset dan Inovasi Nasional Republik Indonesia melalui dana Hibah Penelitian Kompetitif Nasional skema Penelitian Dosen Pemula tahun 2020. Terima kasih kami kepada LLDikti Wilayah 7 yang telah memfasilitasi penelitian kami. Terima kasih juga kepada Wa Nur Dhuha Ramadhana, Putri Anggraini, Nona Maria Engelina Luase dan Putri Rahayu (mahasiswa Fakultas Ekonomi Universitas Yos Soedarso Surabaya) yang telah membantu penelitian ini dalam pengumpulan data kuesioner, wawancara responden penelitian di lapangan sepenuhnya, dan perekapan data hingga selesai, serta Aulia Herdhyanti (mahasiswa Teknik Informatika Universitas Brawijaya Malang) yang telah membantu pengolahan data penelitian ini.

\section{DAFTAR PUSTAKA}

Abdillah, R. M., \& Suryawan, I. B. (2019). Strategi Pengembangan Lumpur Lapindo Sebagai Wisata Edukasi Di Kabupaten Sidoarjo Jawa Timur. Destinasi Pariwisata, 7(2), 281-287.

Arifin, M. Z., Nugroho, W. B., \& Kamajaya, G. (2006). Lumpur panas lapindo: lahirnya subyek dan perubahan sosial, 1-5.

Arsiyah, Ribawanto, H., \& Sumartono. (2009). Pemberdayaan masyarakat dalam pembangunan ekonomi desa. Wacana, 12(2), 370-375.

Bahransyaf, D. (2009). Pemberdayaan masyarakat pasca bencana berbasis penelitian. Jurnal Penelitian Dan Pengembangan Kesejahteraan Sosial, 14(01), 47-56.

Daulay, P. (2010). Survival Mechanism Victim Houshold of Lumpur Lapindo in Sidoarjo - Jawa Timur. Jurnal Organisasi Dan Manajemen, 6(1), 74-88. Retrieved from http://jurnal.ut.ac.id/index.php/JOM/article/download/284/237/

Ekawati, J., Hardiman, G., \& Pandelaki, E. E. (2020). Studi Komparasi Kebertahanan Kota Pasca Bencana Alam City Resilience Post Natural Disaster, A Comparison Study. Arsitektura, 18(1), 129-139.

Elika, elmaghfira putri, Resnawaty, R., \& Gutama, arie surya. (2017). Bencana Sosial Kasus Lumpur Pt.Lapindo Brantas. Jurnal Penelitian \& PKM, 4, 205 216.

Habibullah.(2013). Kebijakan Penanggulangan Bencana Berbasis Komunitas: Kampung Siaga Bencana dan Desa/Kelurahan Tangguh Bencana. Informasi, 
18(02), 133-150.

Hutomo, M. Y. (2000). Pemberdayaan Masyarakat dalam Bidang Ekonomi: Tinjauan Teoritik dan Implementasi. In Pemberdayaan Masyarakat (pp. 111). Jakarta: Bappenas RI. Retrieved from https://www.bappenas.go.id/files/ 2913/5022/6062/mardi_20091015151035_2384_0

Iftita, M., \& Zurinani, S. (n.d.). Penyintas di Lumpur Tanpa Batas : Potret Pemulihan Sosial Ekonomi Masyarakat Terdampak Bencana Lumpur Lapindo, 8393.

Jokowinarno, D. (2011). Mitigasi bencana tsunami di wilayah pesisir lampung. Jurnal Rekayasa, 15(1), 13-20.

Kusumastuti, R. D., Viverita, Husodo, Z. A., Suardi, L., \& Danarsari, D. N. (2014). Developing a resilience index towards natural disasters in Indonesia. International Journal of Disaster Risk Reduction, 10(PA), 327-340. https://doi.org/10.1016/j.ijdrr.2014.10.007

Maarif, S., Damayanti, F., Suryanti, E. D., \& Wicaksono, A. P. (2012). Initiation of The Desa Tangguh Bencana Through Stimulus-Response Method. Indonesian Journal of Geography, 44(2), 173-182.

Mundakir. (2011). Dampak Psikososial Akibat Bencana Lumpur Lapindo ( Psychosocial Impact of Lapindo Mud Disaster ). Jurnal Ners, 6(1), 42-49. Retrieved from https://www.researchgate.net/publication/327338876

Mustangin, Kusniawati, D., Islami, N. P., Setyaningrum, B., \& Prasetyawati, E. (2017). Pemberdayaan Masyarakat Berbasis Potensi Lokal Melalui Program Desa Wisata di Desa Bumiaji. Sosioglobal., Jurnal Pemikiran Dan Penelitian Sosiologi, 2(1), 59-72.

Novenanto, A. (2016). Membangun Bencana: Tinjauan Kritis terhadap Peran Negara dalam Kasus Lapindo.Masyarakat, Jurnal Sosiologi, 20(2), 159-192.

Oktari, R. S. (2019). Peningkatan Kapasitas Desa Tangguh Bencana. Jurnal Pengabdian Kepada Masyarakat, 4(2), 189-197.

Reizkapuni, R., \& Rahdriawan, M. (2014). Pemberdayaan Masyarakat dalam Penanggulangan Banjir Rob di Kelurahan Tanjung Mas Kota Semarang. Jurnal Teknik PWK, 3(1), 154-164. Retrieved from http://ejournal- 
s1.undip.ac.id/index.php/pwk

Salami, R. O., Von Meding, J. K., \& Giggins, H. (2017). Urban settlements' vulnerability to flood risks in African cities: A conceptual framework. Jàmbá:Journal of Disaster Risk Studies, 9(1). https://doi.org/10.4102/ jamba.v9i1.370

Saroji, Mahdi, S., \& Srimulyani, E. (2016). Kajian empiris program desa tangguh bencana (destana) terhadap ketangguhan masyarakat pesisir dalam menghadapi bencana tsunami: studi kasus di dua gampong pesisir kabupaten aceh besar. Jurnal Ilmu Kebencanaan (JIKA), 3(4), 142-148.

Suryaningsih, A., \& Handayani, B. L. (2017). Bertahan Hidup Dalam Kubangan Lumpur ( Studi tentang Korban Lumpur Lapindo di Desa Glagaharum Kecamatan Porong Sidoarjo ) Survive in Mud ( The Study of Lapindo Mudflow Victims in Glagaharum Village, Porong. E-SOSPOL, IV(1), 6-11.

Yoo, S., Butler, J., Elias, T. I., \& Goodman, R. M. (2008). The 6-Step Model for Community Empowerment: Revisited in Public Housing Communities for Low-Income Senior Citizens. Health Promotion Practice, Vol. XX(No. XX, xx-Xx), 1-14. https://doi.org/10.1177/1524839907307884

\section{Buku :}

Anwas, Oos M. 2013. Pemberdayaan Masyarakat Di Era Global. Bandung: Alfabeta.

Adi, Fahrudin. 2012, Pengantar Kesejahteraan Sosial. Bandung. PT Refika Aditama.

\section{Organisasi atau Perusahaan :}

[BNPB], Badan Nasional Penanggulangan Bencana. Dapat diunduh dari: http://bnpb.cloud/dibi// grafik3a (diakses28/08/2020)

\section{Dokumen Hukum, Peraturan dan Perundangan:}

Peraturan Daerah Kabupaten Sidoarjo nomor 6 Tahun 2009 tentang Rencana Tata Ruang Wilayah Kabupaten Sidoarjo Tahun 2009-2029

Undang-undang No 24 tahun 2007 tentang Penanggulangan Bencana 